\title{
A phenomenology of children exposed to the violent conflict in Jos Nigeria.
}

\author{
Musa, Sallek Yaks ${ }^{1}$ \\ ${ }^{I}$ (Department of Criminology, Faculty of Social Sciences, University of Northampton, United Kingdom)
}

\begin{abstract}
Intermittently, the Jos violent conflict has lingered for over a decade, seemingly insurmountable with dire consequences. Research inquiry reveals little or no attention is given to the plight and concern of children exposed to the violence. Using typical case purposive and multiple case sampling techniques, sixty school children within age 14-17 years from six secondary schools were sampled in Jos South and North local government areas for the study. Findings indicate that the children are acutely exposed to the violence as direct victims and witnesses. A new patterned system of relationship involving discrimination and intolerable existence on the basis of identity affiliation has emerged therefrom. High suspicion, fear of and living in fear of getting attacked are among the direct consequences of this violence. The future of this society with children socialised into viewing violence, rivalry, distrust and enmity as a normative pattern of relationship and association is a conundrum for exploration.
\end{abstract}

Keywords: distrust, enmity, identity violence, residential compartmentalisation, rivalry.

\section{Introduction}

Jos, a North Central City of Nigeria, once renowned for its temperate weather, beautiful attraction, a tourist delight, peaceful co-existence, and a hospitable people has overtime outlived this glory [1]. Geographically, Jos the capital city of Plateau State is seemingly, a microcosm of Nigeria, inhabited with vast heterogeneous and ethno-religious groups of native and settlers from all over the country [2].Alozieuwa observed to this effect that the State composition is "a predominantly Christian area situated in the predominantly Muslim North of Nigeria" [3].It is placed in North Central Nigeria with Jos the state capital populated by about 816,876 people [4].

The city has for over a decade now transformed into an atmosphere of violence, incessant conflict, killing and bloodshed (ibid). This sporadic, yet intermittent upsurge of violence has gained momentum and increased in sophistication with stunning increase in the use of deadly weapons and military type assault ammunitions [5]. Observing the trend, Higazi concluded summarily validating the reality of the occurrence by contending that the State has turned into "the main site of ethnic and religious violence....with recurrent crises across the State, in both urban and rural areas" [6].

Conflicting reports have been provided regarding the causes of the conflict which is quite too difficult to accentuate. Many studies argue it as a product of socio-economic, political scramble and competition over allocation, appointment and distribution of the scarce resources and political positions in the State (ibid). However, others connect it to identity problematic emerging from the cultural heterogeneity of the State, religious intolerance and the delineation of people into indigenes and settlers as favoured by the constitution of the country [7].

The causes of the conflict are not of great importance to this study due to the vast availability of research reports and inquiry on it, but it is of eminence to emphasize that the manner in which the violence is expressed and manifested is clearly along ethno-religious lines between Christians and Muslims [8]. For this reason, delineating the violence as an identity conflict aligns favourably with its mobilisation and expression. This expression of intermittent violence takes place within streets and communities, residential areas, markets and business districts, religious places of worship and institutions of learning. The implication of this is that the conflict, tense atmosphere, violence outpour, manslaughter and burning of properties happens right within the view of children. Uba, Kidmas, Sule \& Nwadiaro did not just support this view but further reported several cases of children suffering as direct targeted victims of the violence [9].

\section{Literature and Conceptual Issues involving Exposure of Children to Violence}

Researching the problems and needs of the child is as crucial as the development of any nation because it's near future lies in their existence [10]. To this regard, Marans \& Cohen among many others enumerated the exposure of the child in violent prone environments [11]. Additionally, they noted that parents and caregivers play crucial role in the development, training and helping children cope with strain arising from such exposure. However, if this task of caring for a child to develop and competently cope with exposure to violence is more 
A phenomenology of children exposed to the violent conflict in Jos Nigeria.

effectively undertaken by parents as contended (ibid), then, it is obvious that attention needs be drawn on the reoccurring Jos conflict in which same parents, guardians and community members play active role in fuelling, perpetrating and encouraging the conflict amidst heavy rationalisation of their actions.

Children are no doubt at various forms of risk including been killed in violent conflict environments and situations. Albertyn, Bickler, van As, Milar \& Rode observed in this regard that "there is no doubt the effects of war extend to the most vulnerable members of society including children" [12]. Children have beyond doubt suffered several forms of violent experiences across various human relationships. They suffer to violence either as actual victims to violence or indirectly through exposure and witnessing [13]. Academics and a wealth of scholars have engaged in active research over the years, observing, documenting and reporting several aspect of life settings where children suffer as a result of violence. They are surrounded by violence in schools, in their communities and over the media [14]. Although the family plays an all important role in providing identity, integrating and socialising the child into the mainstream society, it has however failed to achieve this, and has on the contrary, presented itself among the lead exposure environment where children witness violence [15].The well-being, plight and rights of the Nigerian child growing up in violent conflict environments is an area that has been largely under-researched and under-reported as well. The Jos violence which this study focuses on presents such clear indication of child neglect. Since its emergence in 2001 as earlier noted, the violent conflict has lingered to date taking varying forms and heightened hostility with children not spared from witnessing or getting victimised to it [16]. Seemingly, the Nigerian child has being exposed and has continued to witness varying levels of community violence. Since the Nigerian civil crisis of 1967, mushrooms of armed conflict and intermittent violence has been recorded in virtually every part of the country which calls for this concern on the wellbeing, plight and rights of the child [17].

Nigeria currently practices the federal system of governance. The system as practiced empowers States to enact and domesticate territorial laws cognisance to its cultural norms and practices. Collectively, the country uses a mixture of the Common, Customary and Islamic Laws as its legal instruments. In 1991, the country ratified the Convention on the Rights of the Child and subsequently enacted the Child Rights Act 2003 in Abuja and other States that have acceded to it explicitly; however, other States yet to ratify it still enforce the Child and Young Persons Act 1958 ( ibid). This legislation does not however deter incidences of varying child abuse and maltreatment as children have either been lured into engaging in violent confrontation in several conflicts or have been subjected to violenceand systemic abuse in conflicts (ibid).

Over the years this incessant violence continues in Jos with several reported news and video evidence of deaths and casualties clearly indicating how children, like adults are targeted and killed. Few such incidences include the widely reported attack at Dogo Nahawa village on $7^{\text {th }}$ March, 2010 which is available on several YouTube channels and many online streams. A recent scene of this bloodshed is recorded in January 2014 at Shonong community in Riyom Local Government Area (LGA).These few cases exemplify instances involving the maiming of children in violence and targeted attacks in Nigeria.Data from the only published study available, Uba et al, provided detailed account on the various forms of injuries inflicted upon children and the death casualties to the Jos conflict between September 7, 2001 and May $2^{\text {nd }}, 2002$ [9].

Uba et al concluded their report observing the need for attention to be drawn on the plights of children. They noted that "the effects of war on children are horrendous in many ways" (2003:111) therefore, the need for timely and adequate intervention. However, against all these, exposure and victimisation of the Nigerian child to such ugly scenarios, research and priority attention is yet to focus on the subject matter. Researchers and policy makers are yet to engage this subject matter despite the need to elicit the views and experiences, management and coping strategies they adapt to annul the strain or its adverse effect on their becoming shaped by the violence and further becoming violent perpetrators. This research study is the first to engage children's violence exposure to the Jos conflict and proffer recommendation from their own point of view. It is structured towards uncovering their experiences, perception and various other unreported areas where they suffer from violence exposure and victimisation.

\section{Research Objectives}

This study uncovers the exposure of children to violence in Jos Plateau State, a violent conflict prone environment in Nigeria. This is achieved by eliciting the experiences these children have, growing up in violent prone environments. It is focussed on achieving the under listed precise objectives:

- To establish children's exposure to the violence.

- Explore their perception of the violence.

- Uncover in view of the ethno-religious manifestation of the conflict, self-reconstruction, identity and attitudinal formation.

- Critically assess the application of self-identity within social context of association with persons of other religious groups, residential compartmentalisation and the no go area delineation of neighbourhoods and business areas in Jos. 


\section{Research Design}

This research was conducted on the social constructivist paradigm. This is in view of the assumption that "social phenomena and categories are not only produced through social interaction but are in constant state of revision" [18]. Through interaction, co-existence and association, the society in which these children live, influences and shapes their reality and social existence. Therefore, their experiences, conduct of living and the meaning they make are socially and historically negotiated, although this is arguably, subjected to modification and redefinition as they interrelate with members of society.

The study further aligns with the presumption that individual actors give meanings to social realities of existence "in the form of multiple, intangible mental constructions, socially and experientially" [19]. Such meanings are not "simply imprinted on individuals but are formed through interaction with others and through historical and cultural norms that operate in individual lives" [20]. Through this interaction with participants, their subjective views of their experiences is elicited, narrowed down into a few categories, and meaning made about it. More also, because the focus of the study is geared towards eliciting lived experiences, qualitative research tradition was used to obtain data for the study. This way, useful, vital and minute information which could have been lost in the research process including body language, the emotional feeling and reaction of the participants are noted and given careful consideration.

One-to-one semi-structured qualitative interview variant was adopted and used. This is because of the distinct feature it has allowing for flexibility, further probing and yet, maintaining the same question guide in all the conducted interviews. Because the research is focused on the Jos conflict, particular focus is given to the entire geographical location making up the Jos municipal as the study population. Jos South and North LGA's were selected as the study population of the research owing to: the political and geographical delineation of the the two as Jos City; and the encounter of the two LGA's with the violent conflict understudy since 2001 [21].

Participant selection was restricted to age bracket fourteen to seventeen (14-17) years. This delimitation is to enusre only participants who have lived for a considerable number of years in the study area, and are old enough to have created an opinion on the conflcit are involved. Other reasons includes ability to gain access to participants within this age bracket for the research; and also their ability to more easily annul any pain when encouraged/comforted, especially due to remembering past hurts; and for their ability to make informed decision as to participate in the research or not. Typical case purposive sampling was adopted to select secondary schools from which participants where sampled. This selection as Bryman notes "exemplifies a dimension of interest" [18], which is, exposure to the violence understudy. Accordingly, three secondary schools in Jos South and another three in Jos North LGA's were selected for multiple case sampling. The criteria used for this are: engaging public schools which are basically, dominated by children of low income earning parents; private schools, which are largely dominated by children of high income earning and highly placed parents in society; and religious/mission schools which involves a mixture of children whose parents are from all walks of life.

Sampling of participants was carried out using the criterion purposive sampling approach given that it only involves participants who meet the requirements for a given research [22]. Three requirements were further used for selecting the sample participants irrespective of gender differences. These are: return of research interview consent form indicating approval from the parent/guardian for the child to be engaged in the study; being within age bracket 14-17 years; and the voluntary consent of the child to participate, albeit, subject on having a lesson free time during school hours. Using these criteria, five students were successfully recruited and used for the study in each of the six schools. Altogether, a total of sixty interviews were conducted for this research study. Data collected is phenomenologically analysed and presented. Creswell opines "the basic purpose of phenomenology is to reduce individual experiences with a phenomenon and ... develop a composite description of the essence of the experience" [20]. This informs the choice of this approach for this study as Moran further substantiated it as "seeking after a meaning which is hidden by the entity's mode of appearing, therefore... how things appear or are covered up must be explicitly studied" [23].

\section{Findings and Discussion}

The outcome of this study, being a phenomenological study set to uncover the exposure of children to the Jos violent conflict provided stunning outcome. The results of the inquiry are discussed below:

\section{Acute Exposure to the Violence}

This research establishes with worrying concern that children living in troubled areas in Jos have been exposed to variying levels of violent confrontations. A clear indication of this is reflected among all the school children sampled for this research. All the participants did confirm been exposed to the violence in different forms. These forms as revealed by the study includes exposure to the violence as direct victims, or through vicarious victimisation, and by reason of inescapable witnessing of the violence. All the participants were atleast exposed as victims/vicarious victims or by witnessing the violent conflict or both. Exposure by reason of 
witnessing the conflict involves the physical presence of children at moments when houses and properties are been burnt, and when physical violent confrontation using guns and several other weapons is carried out. Whereas, victimisation involves attacks directed at children and vicarious victimisation in this case involves attack meted on a close relative or properties such as a family house. Such physical violent confrontation is perpetrated using arms and several forms of weapons/instruments such as guns and rocket propellers, cutlasses, machetes, clubs, diggers, mallets and sticks $[9,16]$.

Although these might not be the desire of the children, often times, they have no option of escaping the violence without been exposed to conflict scenes. Reason for this is because the violence is actually happening in their neighbourhood, or the neighbouring street. By this therefore, there tends to be no escaping the site of the violence. Some participants recalled:

Most of the place where they started burning and killing was close to us and there is a shop owned by one of our colleague that was burnt while we watched in hiding.

We were living in our house which was an upstairs. Just then we heard gunshots and, from the house, we could see what was happening through the window. So, we discovered they were burning houses and people were running up and down. Some were forced out of their house, while we were only lucky our house was the last along the street. So before they got to our house, we had already moved out and escaped.

The bottom line therefore is, children always stand a high tendency of witnessing violent conflict in their street or at other places they may find themselves once the conflict erupts. Educing from this, it is clear that as much as conflict pervades, children who reside in such conflict environments, children passing by or even in schools continue to remain vulnerable and at heights, suffer inescapably as witnesses to violence.

Conversely, actual victimisation is suffered by many children in several environments including places of worship and learning. An instance of this is the revelation by some children on how their school came under attack:

We were actually writing exams in the School then when they came to the School with sticks, machetes and all sorts of weapons demanding that all students and staff who are not their religion be handed over for them to finish us. It was the quick response of the military who were called upon by the proprietor of the school that helped rescue us from been killed that day. I cried uncontrollably beholding the sight of death, but, they did not have a single pity on us

This experience reveals the depth and extent at which the conflict is deeply rooted. It is rather devastating and unimaginable that children in schools of learning have been made a target for attack by conflicting parties. Reason for attacking children as Albertyn et al.observed is perviewed in an African adage, "to kill the big rats, you must kill the little rats first"'[12]. Therefore, more reason why children likewise adults are attacked and killed in the violence. Sadly also, the incidence does not end with children in schools alone, but at any place found vulnerable incuding their streets as this child narrates:

When we came out from our house, we tried coming out through the main road hoping to have a clear road to run to safety. But we were spotted and chased after with machetes and sticks, some even had guns. My elder brother was unfortunate and was stabbed.

Invariably, many others have suffered indirect victimisation by receiving traumatic news about the loss of a family member or close relative, a friend, personal/family belonging such as houses or properties, hence, vicariously victimised. All these illustrates clearly, children's exposure to the violence under study, hence, validating the relatively dated research by Uba et al. 2003.

\section{Identity Conflict}

One may allude to the conflict as an indigene-settler violence. However, as data from the study provides, the manifestation of violence indicates spatial differences between the religious groupings. This is because Muslim migrants so identified as settlers [5] share a distinct religious belief, hence, making the conflict appear quite multi-faced as an indigene-settler violence and among two contending religious groups, that is, between Muslims and Christians. The manner at which the conflict is perpetuated as uncovered is apparent to the participants. This weighs heavily on their level of exposure to the conflict, thus, informing consensual agreement and delineating it as a Muslim-Christian façade with political and economic undertones arising from political gimmicks by political players whose interest further fuels the confrontation. This consideration arises from reasoning that individuals do not confront each other on a one-on-one basis but by re-grouping on the basis of religious likeness. And although mere quarrel and argument among two persons can be the starting point [2], the conflict in its general sense involves members of the two religious groups confronting each other at the point of occurrence and unleashing the violence.

Muslims do not kill themselves or burn each other's houses and properties, the same with Christians. It is therefore between Muslims and Christians, that is why we now live apart. And, if you go to their area, you are finished. A man went to buy from a market at their area and that was his end. Another man that I know just 
passed through their area to go to work and since then, he has not been seen or found. It is therefore a fight between Muslims and Christians and not just the Plateau indigenes.

The foregoing opinions curled from participants highlights the level at which the relationship between Muslims and Christians is, at conflict. It further validates Ambe-Uva's view of the violence as an identity fuelled violence, hence, the re-occurrence over years, intermittently [1]. More also, the possible marginalisation of Muslims from governance and their treatment as settlers at the State level of administration and appointments denies them gainful opportunities, hence, the resolve to struggle to any extent possible towards achieving this aim (ibid). This has therefore heightened the spread of violence between Christians and Muslims as a religious conflict.Bearing the name Christian or Muslim is therefore a badge indicating belonging to the group against or for the other. Affiliating or sharing a particular religious belief is therefore a mark of belonging to one of the group in conflict, hence, automatically becoming vulnerable of been confronted irrespective of the involvement, disapproval or appreciation or support an individual has of the conflict.

\section{Weak State Response and Political Craftiness.}

Fault has has been attributed on the State response to the violence as been weak, inadequate and failing. This opinion emanates from concerns that the State has the machinery of social control and the maintenance of peace and orderliness. Unfortunately though, the power and coercive instruments available to the State to mediate between the conflicting parties and contain the situation is percieved as inadequately engaged in the view of the participants.

The problem is with the government and its agencies because of their inability to stop the conflict. Supposing I am a leader ruling Mr A, B, and C, if Mr C commits crime, I should call him and punish him and show him that what he did is wrong. But if I fail to, then, everyone would see what $\mathrm{Mr} \mathrm{C}$ did as right and nothing wrong with it, so, such behaviour would always continue again.

The quote above specifically blames the State for failing to adequately engage a punitive criminal justice system which spares no offender such as the just desserts model recommends [24]. Indeed as the children observe, failure to punish offenders does set a precedence for others to overlook a wrongful act and consequently, engage in perpetuating the same act. This opinion therefore provides more support for the long perpetuity on the violence with no foreseeable end as Ambe-Uva posits the possibility of its resurgence at anytime as highly likely. Data further reveals in no uncertain terms, political motives behind the manifestation of the violence. Attention is drawn to the 2007 Jos North violence as erupting because of the local government election results which was largely members of opposing religious group who considered it largely rigged. This opinion suggests the craftiness of State officials in the tussle for power as a contributory factor. This, as Best \& Rakodi (2011) allude, accounts further for the inability of the State to respond effectively and adequately towards putting an end the violence overtime. Identified delimiting factors contribute to the grossly inadequate State response towards containing the violence: the constitution which enshrines superior power on the Inspector General of Police on whose authority State Police Commisioners act although State governors are the executive heads overseeing each State and the Police Commisioner enforcing compliance to the law, stability and orderliness, delimits the ability of the Governor to issue out instructions for immediate action to contain any spate of violence; also, security agents and the military collaborating as special task force have been associated withcomplicity, hence, leading to the loss of confidence of the public on the security agents, and at heights, the demand for their total withdrawal from certain localities after been badly affected by attacks at locations not far from the post or check-points of the security agents.

\section{Identity Re-construction and Intricacy in Social Relationship}

Data from this study corroborates many other studies presenting the conflict as an inter-group contention. This common group identity results into self-consciousness, retracting to group of common by individual members and the re-construction of their identity along same line. Closely connected to Sherif \& Sherif [25], identity formation is established as the first component of intergroup relations in the presence of conflict. Because individuals have recognised the spate of violence as an identity conflict, consciousness of belongingness and similar affiliations arises, thereby resulting to reshaping and patterning inter-personal relationship within group context. This is because of the perceived and existing danger of being confronted by persons of opposing groups, the dogmatic interpretation and compliance to religious teachings, values and entrenched beliefs. This group feeling forms the basic tool for perpetuating violence, and also, the same line by which inter-personal relationship is constructed. Therefore, children likewise elderly members of society fashion new lines of relationship, recognising the impending danger of associating with persons of different group affiliations.

This new patterned relationship provides some form of shield, especially because it is safe being in company of persons sharing similar values who would at any time react to any threat to one as threat to all. Therefore, self-identity tends to become fluid and apparently, reconstructed to suit the environment and situation 
one finds him or herself in. Self-identity is hence replaced by affiliating oneself to either of the confronting religious groups - Christianity or Islam. Such identity reconstruction takes several forms including change of name to suit the religious group in company of, denouncing one's religious group and making false pretence of belonging to opposing group amidst perceived danger. This identity reconstruction is often precautionary due to the fear of unforeseen occurrences and also, a mechanism to escape moments of great danger. Accordingly, inter-personal relationship with members of opposing group is also reduced to the barest level or completely stopped to avoid crossing into zones of danger.

Consciousness of risk exposure and living in fear as observed and deduced is at heights. High level of suspicion exists for strangers whereas unfamiliar faces stand high chances of getting confronted physically, even at moments of relative peace. Therefore there tends to be rapid assessment at all times of where to go to; when to move out; how to move out; which route to pass through; and individuals tend to place themselves at red alert questioning why things are the way they are at every moment and place they find themselves. This is basically because there still remain high chances of violence erupting at any given time. Beyond doubt, consciousness of risk exposure exists among persons of all age, sex and religious groups. As a result, large segment of persons especially the children interviewed live in fear which is worsened by their distrust on the ability of security agencies to contain the violence anytime it erupts. This is due to this consciousness of risk exposure which is also exacerbated by entrenched religious beliefs.

\section{New Patterned Social Relationship}

Emerging from risk of exposure and living in fear is a complex pattern of relationship and association. This new defined pattern of association revolves around three cyclical components: distrust; rivalry; and enmity. Associating with members of opposing religious group is inevitable as trading, public transport and healthcare facilities, schools, commercial and work related offices/districts makes such certainly definite. As a result of the pervasive nature of interaction in the same society which they all co-exists, strained relationship becomes quite obvious with everyone been suspicious of the other. Children are however at more disadvantaged position as they are often unaware of reasons why parents and elderly members of their group of affiliation dictate who to associate with, where not to go and of course what to say when in company of children of opposing group in schools and other public places they happen to meet.

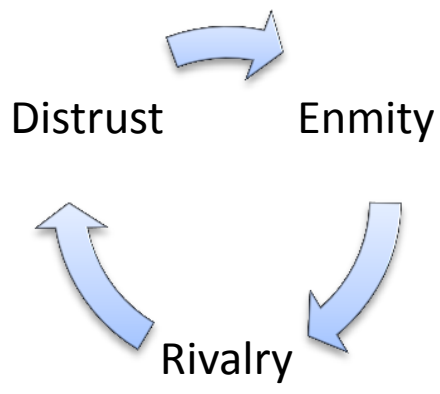

Figure 1.1: New Patterned social relationship

This unhealthy relationship and rivalry tend therefore to be the defining basis for interaction, association and correlation. The deep rootedness of the violence having gained a place over a decade in the study area has within the time been, redefined and altered patterns and mode of livelihood and association in its entirety. Proverbially, a participant concisely captured it thus: living in the same yard with a chicken is no guarantee that it cannot be slaughtered. Hence, distrust pervades and in turn, impedes tolerance and peaceful coexistence, thereby setting room for enmity. In the presence of this, compartmentalisation and differentiation sets in, thus, interrelationship and tolerance becomes dwindled thereby setting room for heightened rivalry and hence revolving the cycle.

Another new patterned relationship which can be visibly noticed yet difficult to correct is the compartmentalisation of residential settlements and in many instances, market hubs and formal elementary schools of learning. By this, Muslims keep off Christian dominated neighbourhoods likewise Christians who all consider such as no go areas, and passing by or visiting such areas could be the end of the person. The implication is, Christians and Muslims no longer live together as neighbours in many such streets. Some markets such as the Gyel market and parts of the Bukuru market is only accessible and used to persons of the same religious identity. Best \& Rakodi attributed this sort of new relationship pattern in the form of relocation and resettlement. Subscribing to their view, it is to date observed that the inability of property owners such as land and businesses to return to their original neighbourhood after the initial violence and the cautious selective consideration of the identity, especially religion of persons seeking to rent properties and the glaring risk of been 
killed upon return has been the major causal factors responsible for the polarisation. This has resulted to a complete redefinition of social life, therefore, integration and visiting Christian occupied neighbourhoods/streets by a Muslim is a near impossibility due to high suspicion, actual existence of risk and fear of been attacked. The multifaceted effect of this on children includes growing up with altered yet, distorted reality of social life; disruption of education as a result of abrupt change of school; growing and imbibing entrenched hatred and anger towards persons of opposing religious identity, poor socialisation and having high tendencies of becoming intolerant of persons whose identity are different from theirs, hence, unequal association and embracing as normative, similar violent attributes they have been exposed to over the years.

\section{Submission and Conclusion}

This study calls attention from the relatively dated study by Uba et al calling on the need to focus attention on children in the spate of violence in Jos. It has further established the exposure of children to the violence and validates the proposition of Albertyn $e t$ al that the effect of violence extends deeply to children in Africa but has been given little or no attention despite the growinng occurences of such violence to date. It is therefore important that government, well meaning and spirited individuals and organisations should rise up to the task of considering the plight, rights and suffering children are bedevilled with in the seemingly, unending violence in Jos, Plateau State Nigeria. This study reveals clearly that attention has not been provided to this category of persons with whom the future of the conflict torn State lies. It is also apparent that their violence exposure distorts their reasoning, association and relationship with persons of opposing religious identity, an attribute, they are likely to hold firm to, grow up with and further develop entrenched dislike and ill-will thereupon. The consequence of these are issues yet to be addressed by this study, though there are indications that these children stand high tendencies of internalising the violent attributes they have grown up knowing and also getting conditioned into accepting them as normative.

An all engaging advocacy, truthful, fair and just reconciliatory mechanism must be adopted by the State towards addressing the spate of violence. Even as at the time of completing this report, more tense is building up in the State with increasing reports of killing and violence in both town and rural settlements. There is the need to revisit and re-address issues regarding settlement and indigeniety in the constitution of the federation even as the proposed February 2015 general elections draws near.The need to tighteen security must also be emphasized. However, the long involvement of military as agents of internal security has also recieved several criticism from members of the public and rights organisation as this study further corroborate for their non civil training, capacity and complicity, hence, the need to re-examine the claims and effectiveness of the strategy currently engaging them as agents of maintining internal security in such conflict torn enviroments.

\section{References}

[1] Ambe-Uva, T. N. (2010). Identity politics and the Jos crisis: Evidence, lessons and challenges of good governance. African Journal of History and Culture, 2(3), 42-52.

[2] Bawa, I., \& Nwogu, V. I. (2002). The Jos crisis. In Centre for Law Enforcement Education (Ed.), Hope Betrayed? A Report on Impunity and State Sponsored Violence in Nigeria (pp. 105-128). Geneva: World Organisation Against Torture and Centre For Law Enforcement Education.

[3] Alozieuwa, S. H. (2010). Beyond the ethno-religious theory of the Jos conflict. Africa Peace and Conflict Journal, 3(2), 18-31.

[4] Nigerian Population Census. (2006). Nigerian Population Census. Retrieved January 21, 2013, from http://www.population.gov.ng/index.php/state-population

[5] Best, S. G., \& Rakodi, C. (2011). Violent conflict and its aftermath in Jos and Kano. What is the role of religion? Religions and development. London: Department For International Development.

[6] Higazi, A. (2011). The Jos crisis: A recurrent Nigerian tragedy. Abuja: Friedrich-Ebert-Stiftung.

[7] Onoja, A. (2010). Reassessing post conflict security in Jos-Plateau: The option of citizens' watch. Afro Asian Journal of Social Sciences, 1(1), 1-15.

[8] Aliyu, A. A., Kasim, R., \& Martin, D. (2011). Impact of violent ethno-religious conflicts on public utilities facilities and services in Jos metropolis of Northern Nigeria. 2011 International Conference on Sociality and Economics Development (pp. 255-262). Singapore: IACSIT Press.

[9] Uba, A. F., Kidmas, A. T., Sule, A. Z., \& C., N. H. (2003). Children in civil crisis: The Jos experience. Nigerian Journal of Orthopaedics and Trauma, 2(2), 109-111.

[10] Bross, D. C. (1991). The Rights of children and national development: Five models. Child Abuse and Neglect: The International Journal, , 15(1), 89-97

[11] Marans, S. \& Cohen, D. (1993). Children and inner-city violence: Strategies for intervention. In L. Leavitt \& N. Fox, (Eds.), Psychological effects of war and violence on children (pp. 281-302). Hillsdale, NJ: Lawrence Erlbaum. Osofsky, J. D. (1999). The future of children. Domestic Violence and Children, 9(3), 33-49.

[12] Albertyn, R., Bickler, S. W., Van As, A. B., Millar, A. J., \& Rode, H. (2003). The effects of war on children in Africa. Pediatric Surgery International, 19(4), 227-232.

[13] Cohen, E., Groves, B. M., \& Kracke, K. (2009). Understanding children's exposure to violence: Moving from evidence to action. The Safe Start Center Series on children exposed to violence. North Bethesda: The Safe Start Center, Office of Juvenile Justice and Delinquency Prevention, Office of Justice Program, U.S. Department of Justice.

[14] Finkelhor, D., Turner, H., Ormrod, R., Hamby, S., \& Kracke, K. (2009). Children's exposure to violence: A comprehensive national survey. Office of Juvenile Justice and Delinquency Prevention. Washington, DC: U.S. Department of Justice.

[15] Bell, C. C. (1993). Community violence and children on Chicago's Southside. Psychiatry, 56(1), 46-54. Huesmann, L. R. (2006). The role of media violence in violent behavior. Annual Review of Public Health, 27, 393-415. 
[16] Horwitz, S. (2005). The functions of the family in the great society. Cambridge Journal of Economics, 29, 669-684. Faller, K. C. (2003). Research and practice in child interviewing: Implications for children exposed to domestic violence. Journal of Interpersonal Violence, 18(4), 377-389. Peddle, N., \& Wang, C. T. (2001). Current trends in child abuse prevention, reporting, and fatalities: The 1999 Fifty State Survey. Chicago: Prevent Child Abuse America.

[17] Best, S. G., \& Kemedi, D. V. (2005). Armed groups and conflict in Rivers and Plateau States, Nigeria. In N. Florquin \& E. G. Berman (Eds.), Armed and Aimless: Armed Groups, Guns, and Human Security in the ECOWAS Region (pp. 12-44). Geneva: Atar.

[18] Adebayo, I. R. (2010). Ethno-religious crises and the challenges of sustainable development in Nigeria. Journal of Sustainable Development in Africa, 12(4), 213-225.

[19] Child Rights International Network. (2013). Inhuman sentencing of children in Nigeria. London: Child Rights International Network .

[20] Bryman, A. (2012). Social Research Methods (4th ed.). Oxford, New York: Oxford University Press.

[21] [Guba, E. G., \& Lincoln, Y. S. (1994). Competing paradigms in qualitative research. In N. K. Denzin, \& Y. S. Lincoln (Eds.), Handbook of Qualitative Research (pp. 105-117). Thousand Oaks CA, London and New Delhi: Sage Publications.

[22] Creswell, J. W. (2007). Qualitative inquiry \& research design: choosing among five approaches (2nd ed.). Thousand Oaks CA: Sage Publications.

[23] Sayne, A. (2012). Rethinking Nigeria's indigene-settlerconflicts. Washington DC: United States Institute of Peace.

[24] Patton, M. Q. (2002). Qualitative evaluation and research methods. London: Sage Publications.

[25] Moran, D. (2000). Introduction to Phenomenology. London: Routledge.

[26] King, M. (1981). The Framework of Criminal Justice. London: Croom Helm. [Sherif, M., \& Sherif, C. W. Groups in harmony and tension. New York: Harper.

[27] Research on intergroup relations. In O. Klineberg, \& C. Richard (Eds.),Perspectives in Social Psychology (pp. 153-177). New York: Holt, Rinehart \& Winston. 